Towards spatial management of fisheries in the Gulf: benthic diversity, habitat and fish distributions from Qatari waters

Walton, Mark; Hayes, Jamie ; Al-Ansi, Mohsin; Abdallah, Mohamed; Al Maslamani, Ibrahim ; Al-Mohannadi, Mohammed; Al-Shaikh, Ismail ; D'Urban Jackson, Tim; Szostek, Claire; Egerton, Jack; Kaiser, Michel; Le Vay, Lewis ICES Journal of Marine Science

DOI:

10.1093/icesjms/fsx116

Published: 01/01/2018

Peer reviewed version

Cyswllt i'r cyhoeddiad / Link to publication

Dyfyniad o'r fersiwn a gyhoeddwyd / Citation for published version (APA):

Walton, M., Hayes, J., Al-Ansi, M., Abdallah, M., Al Maslamani, I., Al-Mohannadi, M., Al-Shaikh, I., D'Urban Jackson, T., Szostek, C., Egerton, J., Kaiser, M., \& Le Vay, L. (2018). Towards spatial management of fisheries in the Gulf: benthic diversity, habitat and fish distributions from Qatari waters. ICES Journal of Marine Science, 75(1), 178-189.

https://doi.org/10.1093/icesjms/fsx116

\footnotetext{
Hawliau Cyffredinol / General rights

Copyright and moral rights for the publications made accessible in the public portal are retained by the authors and/or other copyright owners and it is a condition of accessing publications that users recognise and abide by the legal requirements associated with these rights.

- Users may download and print one copy of any publication from the public portal for the purpose of private study or research.

- You may not further distribute the material or use it for any profit-making activity or commercial gain

- You may freely distribute the URL identifying the publication in the public portal ?
}

Take down policy

If you believe that this document breaches copyright please contact us providing details, and we will remove access to the work immediately and investigate your claim. 
ICES Journal of Marine Science (2017), doi:10.1093/icesjms/fsx116

\title{
Towards spatial management of fisheries in the Gulf: Benthic diversity, habitat and fish distributions from Qatari waters.
}

\author{
Mark E. M. Walton ${ }^{1 *}$, Jamie Hayes ${ }^{1}$, Mohsin Al-Ansi ${ }^{2}$, Mohamed Abdallah ${ }^{3}$, Ibrahim Al \\ Maslamani ${ }^{4}$, Mohammed Al-Mohannadi ${ }^{3}$, Ismail Al-Shaikh ${ }^{4,5}$, Tim D'Urban Jackson ${ }^{1}$, Claire \\ Szostek $^{1}$, Jack Egerton ${ }^{6}$, Michel J. Kaiser ${ }^{6}$, Lewis Le Vay ${ }^{1}$ \\ ${ }^{1}$ Centre for Applied Marine Sciences, Bangor University, Menai Bridge, Wales, UK \\ ${ }^{2}$ Biology Department, Qatar University, \\ ${ }^{3}$ Department of Fisheries, Ministry of Municipality and Environment, State of Qatar \\ ${ }^{4}$ Environmental Science Center, Qatar University, \\ ${ }^{5}$ ExxonMobil Research Qatar, Qatar Science and Technology Park - Tech 2, PO Box 22500 \\ Doha, State of Qatar \\ ${ }^{6}$ School of Ocean Sciences, Bangor University, Menai Bridge, Wales, UK.
}

*Corresponding author: e-mail: m.walton@bangor.ac.uk

Walton, M. E. M., Hayes, J., Al-Ansi, M., Abdallah, M., Al Maslamani, I., Al-Mohannadi, M., Al-Shaikh, I., D'Urban Jackson, T., Szostek, C., Egerton, J., Kaiser, M. J., and Le Vay, L. Towards spatial management of fisheries in the Gulf: benthic diversity, habitat and fish distributions from Qatari waters. - ICES Journal of Marine Science, doi:10.1093/icesjms/fsx116.

Received 21 March 2017; revised 12 May 2017; accepted 21 May 2017.

\section{Abstract}

As with many other regions in the world, more complete information on the distribution of marine habitats in the Gulf is required to inform environmental policy, and spatial management of fisheries resources will require better understanding of the relationships between habitat and fish communities. Towed cameras and sediment grabs were used to investigate benthic habitats and associated epifauna, infauna and fish communities in the central Gulf, offshore from the east coast of Qatar, in water depths of between 12 and $52 \mathrm{~m}$. Six different habitats were identified: i) soft sediment habitats of mud and ii) sand, and structured habitats of iii) macro-algal reef, iv) coral reef, v) mixed reef, and vi) oyster bed. The epibenthic community assemblage of the mud habitat was significantly different to that of sand, which in turn differed from the structured habitats of coral reef, mixed reef and oyster bed, with the macroalgal assemblage having similarities to both sand and the other structured habitats. Fish assemblages derived from video data did not differ between habitats, although certain species were only associated with particular habitats. Epibenthic diversity indices were significantly lower in mud, sand and macro-algal habitats, with no 
differences recorded for fish diversity. Soft sediment grab samples indicated that mud habitats had the highest benthic diversity, with Shannon-Weiner values of $>4$, and were more diverse than sand with values of 3.3. The study demonstrates high biodiversity in benthic habitats in the central and southwestern Gulf, which may in part be due to the absence of trawling activity in Qatari waters. There is a strong influence of depth on benthic habitat type, so that depth can be used to predict habitat distribution with a high level of accuracy. The presence of outcrops of hard substrata creates a mosaic of patchy shallow structured benthic habitat across extensive areas of the offshore seabed. Such heterogeneity, and the association of commercially-exploited fish species with specific habitats, indicates that this region is well suited to a spatial approach to fisheries management.

Keywords: Biodiversity, benthos, habitat, fish density, spatial management, ROPME Sea Area, Arabian Gulf.

\section{Introduction.}

Marine habitats in the Gulf, in the ROPME Sea Area, face significant anthropogenic pressure resulting from oil and gas extraction, coastal reclamation, fishing and pollution (Sale et al. 2011, Naser 2014). These pressures occur against a background of an increasing frequency of extreme temperature events (Riegl et al. 2011). Understanding and managing the impacts of these pressures on marine habitats are severely compromised by lack of data on the distribution and extent of habitats that exist in the Gulf, (UNEP 2009). Since the introduction of the Convention on Biological Diversity countries became legally obliged to develop a strategy for the conservation and sustainable use of biological diversity, and the importance of marine and coastal biodiversity was recognised early on at the first Conference of Parties (COP 1). All the Gulf States have either ratified or acceded to the CBD and have either produced a National Biodiversity Strategy and Action Plan (NBSAP) or are implementing measures to satisfy obligations to the CBD (CBD, 2016). NBSAPs consist of strategic goals that include setting up of protected areas, protecting and conserving marine and coastal resources, enforcing environmental legislation and supporting scientific research that can better inform decision makers (CBD 2016). In 2006 a target of $10 \%$ of all ecological regions were to be protected by 2012; this was later revised at the COP 10 increasing the terrestrial target to $17 \%$ but the marine target was maintained at $10 \%$ by 2020 (CBD 2010). However, in order to achieve these targets countries will need to understand better the inventory of different benthic species and habitats that occur in their national waters within the EEZ.

The unique habitats that exist in the Gulf are a consequence of the sea's isolation and extreme environment due to the restricted water exchange with the Gulf of Oman, combined with high evaporation $\left(>2,000 \mathrm{~mm} \mathrm{yr}^{-1}\right.$ ) (Hunter 1983) and low freshwater input that results in great seasonal water temperature variation $\left(10-40^{\circ} \mathrm{C}\right)$ and high salinity $(36-60 \mathrm{ppt}$ ) (Sheppard et al. 1992, Al-Maslamani et al. 2007). The low energy environment of the Gulf means that 
the dominant benthic habitat is mud which can stretch from intertidal salt marshes to the deepest waters at around $90 \mathrm{~m}$, with coarser sediment occurring in areas with greater hydrodynamic energy (Sheppard et al. 2010). Intertidally and in shallow waters, these muddy habitats can be extremely productive due to the formation of dense algal mats dominated by cyanobacteria and diatoms that support coastal food webs and commercially important species including both fish and shrimp (Al-Zaidan et al. 2006). Seagrass beds are another highly productive habitat with above-ground biomass of as much as $900 \mathrm{~g} \mathrm{DW} \mathrm{m}^{-2}$ on the east coast of Qatar (Walton et al. 2016), more than ten times than reported for this species from elsewhere in the world (Duarte and Chiscano 1999). Macroalgae can form dense beds where hard substrata provide point of attachment, and form an important component of the detrital loop (Sheppard et al. 2010). The apparent high productivity in these habitats is consistent with the idea of Jones et al. (2002) that shallower subtidal and intertidal areas in the Gulf are more productive than deeper offshore waters, with recent studies suggesting that much inshore fauna appears to be nutritionally reliant on these habitats (Al-Zaidan et al. 2006, AlMaslamani et al. 2007, Walton et al. 2014). Among the predominant soft sediments found offshore, shallower limestone outcrops also occur, composed of ancient limestone domes or more recent diagenetic limestone, that are colonised by benthic epifauna including corals and oysters (Riegl 1999, Sheppard et al. 2010). While lacking the structural complexity of tropical reefs, these oyster and coral habitats are important in terms of both faunal biodiversity and biomass, and are one of the most productive habitats in the Gulf (Sheppard et al. 1992). In areas closer to the coast, patchy corals may colonise areas of hard substrate with better developed coral reefs occurring further offshore (Sheppard et al. 2010). Pearl oyster beds (Pinctada radiata oyster beds occur mostly on hard substrata at depths of between 12 to 16 m (Al-Khayat and Al-Ansi 2008) and sometimes within patchy coral areas (Smyth et al. 2016). The literature records more than 22 named offshore limestone outcrops with coral rich areas and oyster beds in Qatar waters alone and preliminary studies report they are associated with at least 158 and 189 species respectively, with many of the species common to both habitats (Al Ansi and Al-Khayat 1999, Al-Khayat and Al-Ansi 2008). These shallow offshore hard substrate habitats and especially oyster beds are targeted by trap fishermen (Al-Maslamani et al. In Prep), but to date there are no reports of linkages between habitats in the Gulf and associated fisheries.

While there is a body of knowledge about coastal and shallow $(<6 \mathrm{~m})$ water habitats in the Gulf (Al-Zaidan et al. 2006, Al-Maslamani et al. 2007, Walton et al. 2014), they are reported to occupy less than $20 \%$ of the Gulf (Sheppard et al. 2010). The majority of the $35,000 \mathrm{~km}^{2}$ of seabed that comprises the Qatar EEZ is comprised of soft sediment habitats in relatively deeper waters (CBD 2016), which are less well studied and little is known about their importance to associated epibenthic and demersal communities.

Many of the species that occur in benthic habitats in the Gulf are already at the edge of their distribution and are subject to significant environmental stress, and this is compounded by the range of users competing for access to coastal and offshore marine space and resources 
(Sale et al. 2011), so that additional pressure from climate change or anthropogenic activities resulting from the rapid coastal development and petrochemical industries can have significant impacts. A number of studies have reported that species diversity in the Gulf is impoverished (eg. Price 1982, Sheppard et al. 1992, Sheppard et al. 2010), although this is not a universal view (Price and Izsak 2005). Commercial fisheries in Qatar are largely artisanal, and the majority of landings are associated with demersal species caught with traditional baited and non-baited traps (gargoor) (FAO 2003). Bottom trawling has been banned since 1992 (Decree 86 issued by Ministry of Municipal Affairs and Agriculture in 1992) and prior to that a closed season ( $1^{\text {st }}$ Feb to $30^{\text {th }}$ June) had been in effect since 1981 (Decree 30 issued by the Council of Ministers, 1981). Bottom trawling is now recognized as one of the most destructive methods of fishing, modifying the seabed morphology and composition of the benthic community (Kaiser et al. 2002) and decreasing both benthic biodiversity and biomass (Hinz et al. 2009). Thus, benthic habitats in Qatar would be expected to be relatively intact compared with neighbouring countries where trawling has continued. This study offers an excellent opportunity to examine the heterogeneity and diversity of offshore benthic habitats utilised by commercial fish species and to inform potential future establishment of ecosystem-based approaches to spatial management of fisheries (Norse 2010).

Qatar's national waters contain habitats representative of those found in the central and southwestern Gulf, with the same range of environmental stressors as found elsewhere in the region. The present study characterises the varied habitats that are present in the offshore waters of Qatar, and tests the hypothesis that these habitats and associated communities are depth dependent. The mapping of benthic habitats in the present study enables an initial quantitative analysis of the commercially important fish species that are associated with each habitat, as a first step towards an ecosystem based approach to the management of habitats and associated fisheries.

\section{Methods}

\section{Description of Habitats}

Forty eight stations were sampled at depths between 12 and $52 \mathrm{~m}$ using the Qatar University research vessel, RV Janan. At each station HD video and photograph images were collected using a towed camera sledge, with a forward facing GoPro camera angled at $45^{\circ}$ and a downward facing digital SLR which was set to take a photo every 20 seconds. Parallel laser pointers were attached to the front of the frame to calibrate the scale of images. 


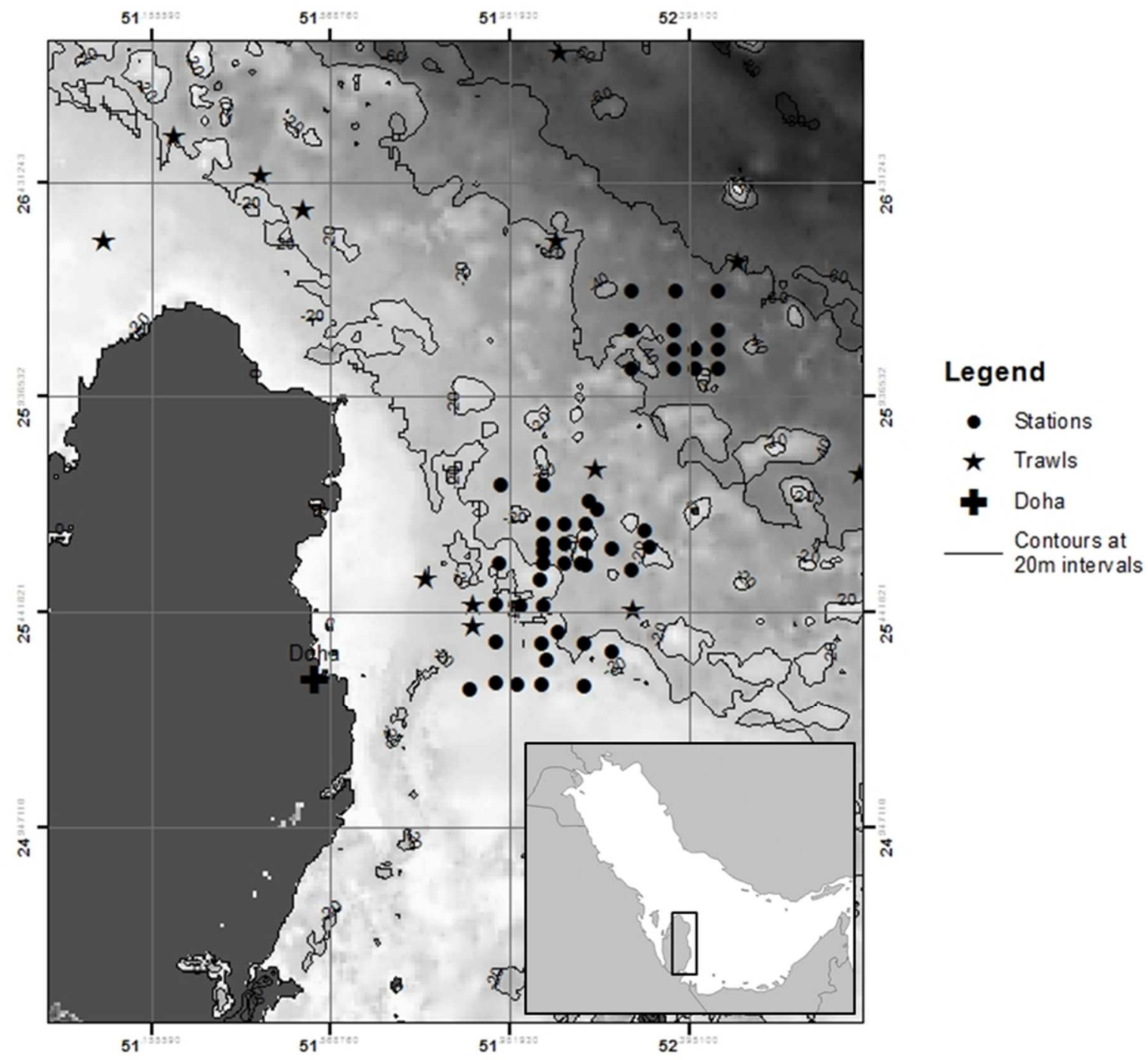

Figure 1: Location of sample stations (circle) and bottom trawl surveys (star). Contour lines show 20 m depth increments. Inset map shows the Gulf and survey area off Qatar.

Camera sledge tows had a duration of 20-30 minutes, with the exact length determined retrospectively from GPS, speed of the research vessel and total bottom time. Each tow was divided into sections for the analysis of fauna. Each of these sections was $0.178 \mathrm{~m} \times 25 \mathrm{~m}$ which gave a sample area of $4.45 \mathrm{~m}^{2}$ in total for each separate section.

For sites with soft sediments, quantitative infauna samples were also collected using three replicate $0.1 \mathrm{~m}^{2}$ Day grabs, at each station. Each sample was mixed and divided in two. Half was processed for grain size analysis and the other preserved in $70 \%$ ethanol for the identification of benthic assemblage. Samples were washed over $0.5 \mathrm{~mm}$ mesh, and retained sediments were then examined under a stereo microscope and all organisms identified to species level when possible.

\section{Video habitat classification}


Following lerodiaconou et al. (2007) the video images (digital) were initially viewed to determine the types of substrata and dominant biota present. Using these preliminary observations of the image data, a habitat classification was devised using a combination of the percentage cover of a sediment type and counts of dominant epibenthic taxa present in each quadrat using decision rules (Table 1 ).

Table 1: Habitat classification and selection criteria based on the number of benthic biota (macroalgae, oyster and coral) and percentage cover of sediment (*sediment classification validated by grain size analysis (see results section)).

\begin{tabular}{lllllll}
\hline $\begin{array}{l}\text { Criteria } \\
\text { Habitat }\end{array}$ & Macroalgae & Oyster & Coral & Sand & Mud & Sediment based on camera images* \\
\hline Macro algal & $\geq 15$ & Absent & $<10$ & & \\
Oyster Bed & $\leq 25$ & $>10$ & $<10$ & & - \\
Coral Reef & $<10$ & $<10$ & $>10$ & & - \\
Mixed Reef & $>10$ & Present & $>10$ & & - \\
Sand & $<10$ & $<10$ & $<10$ & $>80 \%$ & $<20 \%$ & Some grains $>1$ mm visible \\
Mud & $<10$ & $<10$ & $<10$ & $<20 \%$ & $>80 \%$ & No grains $>1$ mm visible \\
\hline
\end{tabular}

\section{Species biodiversity}

All epibenthic organisms and fish were recorded and identified from the video footage to either family or species level (S.I. 1). If species level identification could not be achieved, taxa within a genus or family were separated according to morphological difference following the CATAMI classification scheme of Althaus et al. (2015), with the image of each taxa archived for comparison with subsequent video footage. Macroalgae were included as pooled classification as it was not possible to separate them due to the variable lighting and image resolution.

Data for fish assemblages and epibenthic communities were analysed by combining both univariate and multivariate analyses, using statistical software PRIMER-E 6 with PERMANOVA extension and SPSS (Clarke and Gorley 2006, SPSS 2013). A fourth root transformation was applied to the abundance data collected to improve the data distribution throughout the analysis (Quinn and Keough 2002). In-fauna data was only available from the two soft sediment habitats and was therefore excluded from ANOSIM and SIMPER analysis.

Multivariate one-way analysis of similarities (ANOSIM) tested the hypothesis that there are significant differences in epibenthic community assemblages between habitats, and these change with increasing depth. Multidimensional scaling (MDS) plots allowed a comparison of computed Bray-Curtis similarities between all sites. SIMPER analysis (analysis of contribution 
to similarity) was used to identify individual epibenthic species that contributed most to dissimilarities between habitats grouped according to the results from the ANOSIM analysis.

Species diversity indices (Species richness $\left(\mathrm{S}^{\prime}\right)$, Pielou's evenness $\left(\mathrm{J}^{\prime}\right)$, Margalef Diversity Index $\left(d^{\prime}\right)$ and Shannon-Wiener (S-W) Diversity Index $\left(H^{\prime}\right)$ ) were obtained using the DIVERSE function in PRIMER using the lowest taxonomic groupings the epibenthic fauna from the video footage (SI 1) and the infauna identified from 3 replicate grab samples. These indices were tested for normality using a Kolmogorov-Smirnov test before being subjected to either a oneway-ANOVA $(P<0.05)$ or Kruskal-Wallis test $(P<0.05)$ to determine if the indices were significantly different. If significance differences were found, a post-hoc analysis (Tukey or Mann-Whitney $U$ ) was implemented to determine which groups were significantly different.

\section{Depth Analysis}

Once each transect was associated with a particular habitat type and depth category (Table 2) a Chi-Square test for association was applied to determine the relationship between depth and habitat type.

Table 2: Depth classes and their associated depth range.

\begin{tabular}{cc}
\hline Depth Category & Depth Range $(\mathrm{m})$ \\
\hline 1 & $10-20$ \\
2 & $21-30$ \\
3 & $31-40$ \\
4 & $41-50$ \\
5 & $\geq 51$ \\
\hline
\end{tabular}

\section{Habitat distribution}

A multinomial probit analysis was used to determine the depth distribution for each of the habitats. Preliminary inspection of results indicated that coral reef, oyster bed, macroalgae and mixed reef habitat depth ranges overlapped, hence thereafter they were combined in into a single category of "structured habitat". The probit analysis showed transition zones at intermediate depths between the structured/sand habitats and the sand/mud habitats, so these were added as classification categories. Once the habitat relationship with depth was determined, a map of the possible distribution of these habitats was created. The map was created by using ArcGIS (10.2.1) (ESRI 2011), with a bathymetric chart obtained from GEBCO and by using the appropriate depth ranges associated with each habitat (GEBCO 2015). The accuracy of the predicted habitat map was determined by the use of a linear regression t-test, which tested the observed habitat types against the predicted habitat types.

\section{Bottom trawling for comercial fish species}


Bottom trawls were carried out as part of the a wider fisheries survey that was performed by Department of Fisheries, Ministry of Municipality and Environment (Qatar) between 2008 to 2012. Of these, 16 stations to the north and east of Qatar were stratified according to depth (Figure 1). Five trawls were performed at each of sixteen station at mean ( $\pm S D$ ) depths of between $9.3 \pm 1.5$ and $67.6 \pm 5.0 \mathrm{~m}$ (see Supplement 1). Bottom trawls were carried out at 3 knots for 30 mins using a net with headline height of $1 \mathrm{~m}$, a spread between doors of $19 \mathrm{~m}$, with a $54 \mathrm{~mm}$ mesh codend and wing panels. The catch was sorted into commercially important species counted and weighed wet on motion compensated balances accurate to 1 g. Biomass data for each species was expressed as catch per unit area bases on swept area using GPS positions for the start and end of trawl.

\section{Results}

\section{Epibenthic species compositions in each habitat}

Video footage indicated macroalgae were present in all habitats, with the greatest frequency occurring in the "macroalgal" and "mixed reef" habitat categories (Table 3). Similarly, corals appear with the greatest frequency in the coral reef and mixed reef habitats. Higher taxonomic level identification (presented in Supplement 1) shows that sea pens, polychaetes, and Actiniaria were found almost exclusively in the sand and mud habitats. All other genera/species recorded during the camera sledge tows were not habitat specific and were recorded in almost all habitats (Table 3).

Table 3: The percentage occurrence of epibenthic taxa within a $4.45 \mathrm{~m}^{2}$ quadrat in each habitat type (\%) identified from camera images.

\begin{tabular}{lcccccc}
\hline Taxa & Oyster Bed & Mixed Reef & Coral Reef & Macroalgae & Sand & Mud \\
\hline Acroporidae & 37.5 & 7.7 & 26.7 & 8.3 & 0 & 0 \\
Actiniaria & 0 & 0 & 0 & 0 & 0.8 & 11.7 \\
Ascidiiae & 100 & 76.9 & 60.0 & 58.3 & 13.1 & 1.0 \\
Chalinidae & 0 & 30.8 & 13.3 & 0 & 0.4 & 0 \\
Clypeasteroida & 37.5 & 23.1 & 6.7 & 8.3 & 5.6 & 0.5 \\
Demospongiae & 75.0 & 7.7 & 40.0 & 16.7 & 9.1 & 3.1 \\
Dendrophylliidae & 87.5 & 100 & 60.0 & 25.0 & 0.4 & 0 \\
Diadematidae & 62.5 & 61.5 & 100 & 0 & 1.6 & 0.5 \\
Holothuriidae & 12.5 & 0 & 33.3 & 8.3 & 0.4 & 0 \\
Macroalgae & 100 & 100 & 26.7 & 100 & 38.5 & 4.1 \\
Mussidae & 25.0 & 69.2 & 100 & 0 & 0.8 & 0 \\
Ophidiasteridae & 25.0 & 61.5 & 13.3 & 0 & 0.8 & 0.5 \\
Pennatulacea & 50.0 & 0 & 6.7 & 25.0 & 11.9 & 65.3 \\
Poritidae & 62.5 & 46.2 & 86.7 & 0 & 1.2 & 0 \\
Pteriidae & 100 & 69.2 & 20.0 & 16.7 & 0.4 & 0 \\
\hline
\end{tabular}




\begin{tabular}{lcccccc}
\hline Sabellidae & 0 & 0 & 0 & 0 & 4.0 & 1.0 \\
Siderastreidae & 12.5 & 46.2 & 40.0 & 0 & 0.4 & 0 \\
\hline
\end{tabular}

MDS analysis indicated that the benthic assemblages found over the sampled habitats clustered into three main groups: mud, sand and the photic-zone structured habitats (SH) (the latter comprised of macroalgal, coral reef, mixed reef and oyster bed) (Figure 2). There were significant differences between the species groupings found across these habitats (ANOSIM, $r=0.636, P=<0.001$ ). A pairwise comparison between all habitats confirmed that benthic assemblages were significantly different (Table 4).

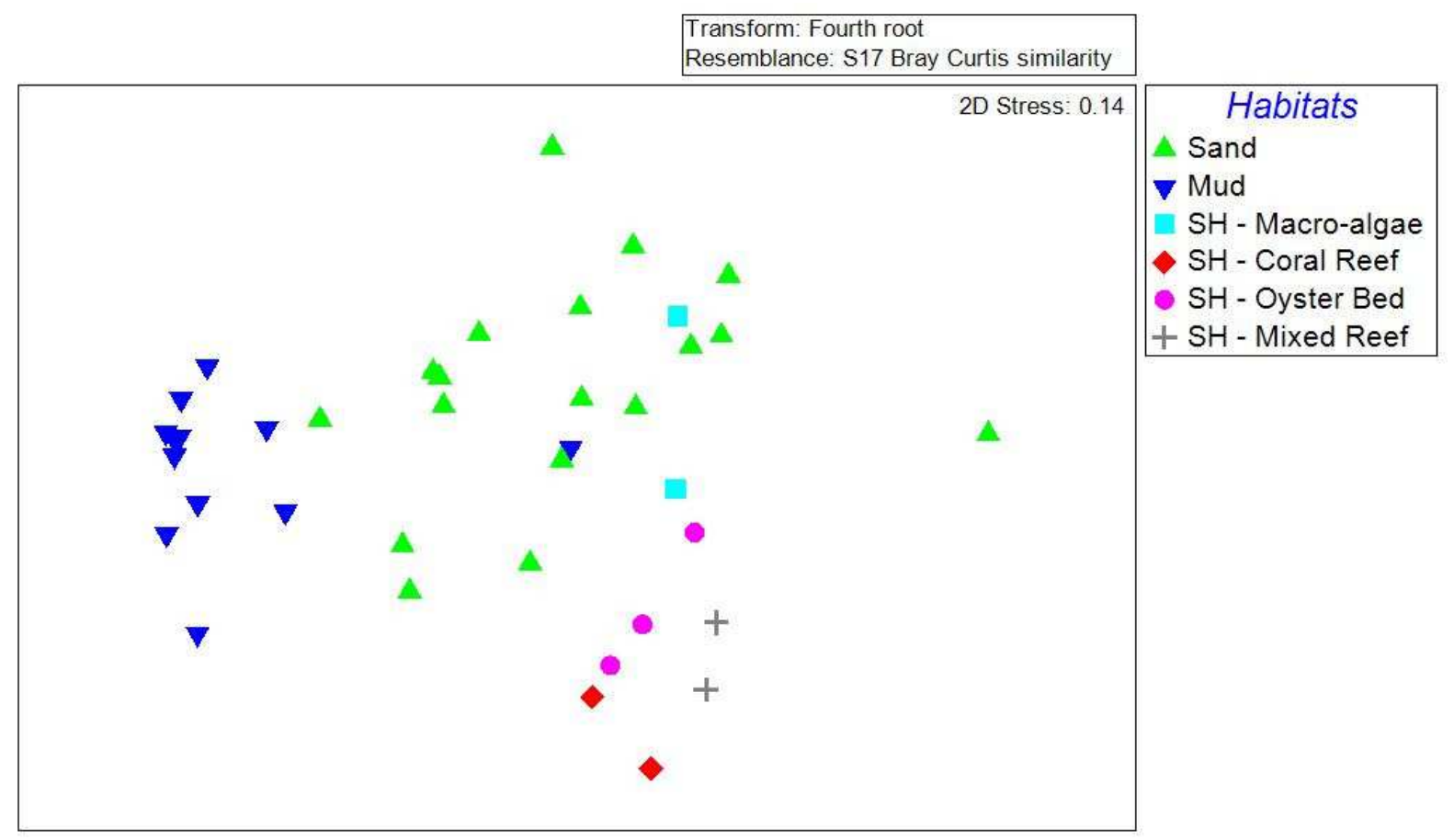

Figure 2: Multi-dimensional scaling plot of the similarity in the community composition of epibenthic species (average density per $4.25 \mathrm{~m}^{2}$ ) for mud, sand and structured habitats (SH) sampled by towed camera survey.

Table 4: Pairwise comparison of benthic community composition in the sampled habitats

\begin{tabular}{lll}
\hline Habitats & R Statistic & P Value \\
\hline Mud and Sand & 0.616 & 0.001 \\
Mud and Structured & 0.937 & 0.001 \\
Sand and Structured & 0.378 & 0.001 \\
\hline
\end{tabular}

SIMPER analysis of the epibenthic community assemblages, showed macroalgae, ascidians (Phallusia nigra), the black long spine urchin Diadema setosum, and sea pens and sea whips 
are the main taxa responsible for dissimilarity between the habitats. The greatest dissimilarities were seen between the mud and structured habitats (90.32\%) that were separated by the greatest depth difference (Table 5).

Table 5: Results of SIMPER analysis showing the top three taxa that differed between habitat classifications. Average dissimilarity in abundance and contribution to the overall dissimilarity is given.

\begin{tabular}{ccccc}
\hline $\begin{array}{c}\text { Habitat } \\
\text { (average } \\
\text { dissimilarity) }\end{array}$ & Species & $\begin{array}{c}\text { Average } \\
\text { dissimilarity }\end{array}$ & $\begin{array}{c}\text { Contribution to } \\
\text { dissimilarity } \\
\text { (\%) }\end{array}$ & $\begin{array}{c}\text { Habitat } \\
\text { where in } \\
\text { greatest } \\
\text { abundance }\end{array}$ \\
\hline Sand \& Mud & Sea pens & 11.28 & 14.34 & Mud \\
(78.64\%) & Macroalgae & 9.81 & 12.47 & Sand \\
& Sea whips & 6.68 & 8.50 & Mud \\
Sand \& Structured & P.nigra & 6.16 & 8.36 & Structured \\
Habitat (73.78\%) & Macroalgae & 5.71 & 7.73 & Structured \\
& D. setosum & 5.62 & 7.62 & Structured \\
\hline Mud \& Structured & Macroalgae & 8.97 & 9.93 & Structured \\
Habitat (90.32\%) & Sea pens & 8.18 & 9.06 & Mud \\
& P.nigra & 7.00 & 7.75 & Structured \\
\hline
\end{tabular}

\section{Infaunal Community}

From the soft sediment grab samples, grain size analysis revealed significantly more sand and less clay in the shallower "sand" stations than the deeper "mud" stations ( $t=28.3, p$ $<0.001$, and $t=6.3, p<0.001$, respectively). Also from the grab samples 603 species were identified and more than 13,000 individuals were counted. The composition of the benthic infauna indicated that annelids and arthropods were the two most important phyla in terms of abundance (Table 6). These phyla, together with other abundant in-fauna such as nemertean, sipunculids and molluscs are not well captured in the video footage.

Significantly greater abundances of annelids, arthropods, nemerteans, and sipunculids were recorded in the shallower sand habitats than in the mud habitats.

Table 6: Mean abundances (inds. $\mathrm{m}^{-2}$ ) of phyla recorded in grab samples of the infauna, (division level in the case of Rhodophyta)

\begin{tabular}{lcc}
\hline Classification & Mud & Sand \\
\hline Rhodophyta & 0 & 0.33 \\
Sarcomastigophora & 12.0 & 11.56 \\
Porifera & 0 & 0.11
\end{tabular}




\begin{tabular}{lcc} 
Cnidaria & 0.657 & 4.33 \\
Nemertea & 0 & 0.33 \\
Nematoda & 5.43 & 26.22 \\
Sipuncula & 1.14 & 26.67 \\
Platyhelminthes & 0 & 0.56 \\
Annelida & 163.986 & 386.33 \\
Arthropoda & 70 & 82.56 \\
Mollusca & 35.986 & 33.22 \\
Echinodermata & 1.14 & 5.33 \\
Brachiopoda & 0 & 0.33 \\
Ectoprocta & 3.71 & 2.89 \\
Chordata & 0 & 1.67 \\
\hline
\end{tabular}

Fish species compositions in each habitat (camera data)

In relation to the mobile fish species, Valenciennea persica was recorded only in the macroalgae habitat. Nemipterus spp., Lepidotrigla bispinosa, Selaroides leptolepis, and Upeneus spp. were found only in the mud habitat. Pseudochromis aldabraensis was recorded exclusively in coral reef habitats and Dussumieria spp., Epinephelinae spp. and Parupeneus margaritatus were recorded only in sand habitats. Gobiidae in burrows were observed in all habitats. All other fish species recorded during the camera tows were not limited to a single habitat (Table 7).

Table 7: The percentage occurrence of the most abundant fish families found in each habitat type within a $4.45 \mathrm{~m}^{2}$ quadrant (\%) and with the coral reef, mixed reef, oyster bed and macroalgae grouped into the structured habitats.

\begin{tabular}{lccccccc}
\hline Taxa & $\begin{array}{c}\text { Coral } \\
\text { Reef }\end{array}$ & $\begin{array}{c}\text { Oyster } \\
\text { Bed }\end{array}$ & $\begin{array}{c}\text { Mixed } \\
\text { Reef }\end{array}$ & Macroalgae & $\begin{array}{c}\text { Structured }= \\
\text { CR\&MR\&OB\&MA }\end{array}$ & Sand & Mud \\
\hline Carangidae & - & - & - & - & 0 & 0.4 & 1.0 \\
Carcharhinidae & - & - & - & - & 0 & 0.4 & - \\
Clupeidae & - & - & - & - & 0 & - & 0.5 \\
Dussumieriidae & - & - & - & - & 0 & 0.8 & - \\
Gobiidae & - & 12.5 & - & 25.0 & 9.1 & 6.3 & 14.8 \\
Lutjanidae & - & - & - & 16.7 & 4.5 & 0.4 & 2.6 \\
Mullidae & - & 12.5 & - & - & 2.3 & 6.3 & 1.0 \\
Paralichthyidae & - & - & - & - & 0 & 0.4 & 0.5 \\
Pomacanthidae & 9.1 & 12.5 & - & 8.3 & 6.8 & 0.4 & - \\
Pseudochromidae & 9.1 & - & - & - & 2.3 & - & - \\
Serranidae & 9.1 & 12.5 & - & - & 4.5 & 0.8 & 1.0 \\
Sillaginidae & - & - & - & 8.3 & 2.3 & 4.4 & 9.7 \\
\hline
\end{tabular}




\begin{tabular}{lccccccc}
\hline Sphyraenidae & - & - & - & - & 0 & - & 2.0 \\
Synodontidae & - & - & - & - & 0 & - & 4.6 \\
Triglidae & - & - & - & - & 0 & - & 4.6 \\
Unidentified. & - & - & 7.7 & - & 2.3 & 2.0 & 4.1 \\
\hline
\end{tabular}

In order to improve the statistical power coral reef, mixed reef, oyster bed and macroalgae habitats were pooled. The mixed distribution in MDS ordination plots suggested fish species were not discriminated by habitat type (Figure 3 and was confirmed by ANOSIM which showed no significant differences between the assemblages of fish in the three habitats (structured, sand and mud, ANOSIM, $r=0.173, p=0.074$ ).

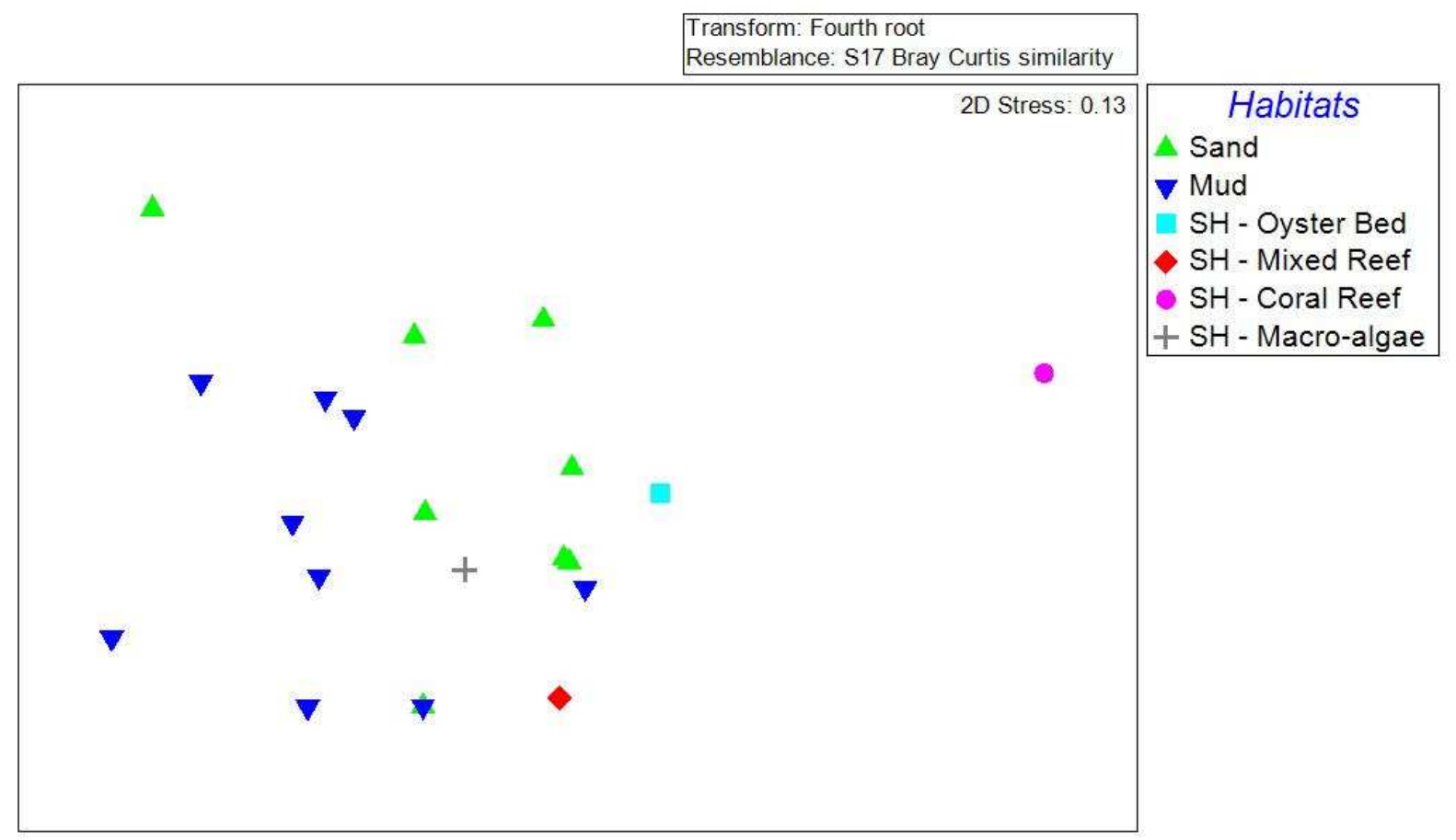

Figure 3: Multi-dimensional scaling plot based on fish species average density per $4.25 \mathrm{~m}^{2}$ for mud, sand and structured habitats (SH) sampled by towed video. The plot shows similarities between sites in regards to their fish community composition in each habitat.

\section{Community Diversity}

Diversity indices, using the lowest identified taxonomic levels identified from the video footage, indicated that mixed reef habitats had the highest epibenthic diversity compared with the other sampled habitats (Table 8a). Sand and mud habitats had the lowest diversities for all indices. Habitats (excluding the grouped structured habitat) were found to have significantly different species richness $\left(X^{2}{ }_{(5)}=19.35, p=0.002\right)$, total individual frequency $\left(X^{2}{ }_{(5)}\right.$ $=16.53, p=0.004)$, Margalef diversity index (ANOVA $\left.F_{(5,31)}=10.47, p=<0.001\right)$ and ShannonWiener $(S-W)$ diversity index $\left(X^{2}{ }_{(5)}=19.14, p=0.002\right)$, while no significant difference were 
found using Pielou's evenness $\left(X^{2}{ }_{(5)}=6.72, p=0.242\right)$. Post-hoc analysis showed that oyster beds and mixed reef had significantly greater Margalef diversity and S-W diversity than mud and sand habitats. Species richness and total individual frequency indices also indicated significantly higher diversity in coral reef compared with mud and sand habitats. Comparison of the epibenthic diversity in the grouped structured habitat with that of mud and sand indicated significant differences in Margalef diversity index $\left(\operatorname{ANOVA~F}_{(2,35)}=3.497, p=0.041\right)$, S-W diversity index (ANOVA $F_{(2,35)}=5.359, p=0.009$ ), species richness $\left(X^{2}(2)=11.81, p=\right.$ $0.004)$, total individual frequency $\left(X^{2}{ }_{(2)}=14.13, p=0.001\right)$, while no significant different were found using Pielou's evenness (ANOVA F $(2,35)=0.788, p=0.467$ ). Post hoc analysis showed that structured habitats had significantly greater Margalef diversity, Shannon-Wiener diversity, total individual frequency and species richness than sand and mud habitats.

Analyses of the Day grab sampled soft sediment communities indicate benthic diversity to be much greater than that captured in the camera data (Table 8b). Grab samples indicated S-W diversity was higher in mud habitats $\left(\right.$ T-test $\left._{(17)}=6.44, \mathrm{P}<0.001\right)$, Pielou's evenness was also higher in mud habitats (Kruskal-Wallis $X^{2}{ }_{(1)}=19.46, p=0.242$ ), but total individual frequency was higher in sand habitats $\left(X^{2}{ }_{(1)}=15.98, p<0.001\right)$. Both S-W diversity and Pielou's evenness were significantly positively correlated with increasing depth of habitat (Pearson correlation $r=0.75, p<0.001$ and $r=0.79, p<0.001$, respectively). No significant differences were detected in species richness and Margalef diversity between mud and sand habitats.

Table 8a: Mean values $(\underline{+S E})$ for the epibenthic community in each habitat sampled by video surveys of species richness (S), total individual frequency $(N)$, Margalef diversity index ( $\left.d^{\prime}\right)$, Pielou's evenness $\left(\mathrm{J}^{\prime}\right)$, and Shannon-Weiner diversity index $\left(\mathrm{H}^{\prime} \log _{\mathrm{e}}\right)$.

\begin{tabular}{lccccc}
\hline Habitat & $\mathbf{S}$ & $\mathbf{N}$ & $\mathbf{d}^{\prime}$ & $\mathbf{J}^{\prime}$ & $\mathbf{H}^{\prime}($ loge $)$ \\
\hline SH-Macroalgae & $4.00( \pm 2.00)$ & $7.09( \pm 3.87)$ & $1.47( \pm 0.62)$ & $0.92( \pm 0.03)$ & $1.16( \pm 0.54)$ \\
SH-Coral reef & $9.50( \pm 2.50)$ & $19.14( \pm 3.99)$ & $2.85( \pm 0.65)$ & $0.96( \pm 0.02)$ & $2.13( \pm 0.31)$ \\
SH-Oyster bed & $9.67( \pm 1.33)$ & $17.28( \pm 2.74)$ & $3.04( \pm 0.33)$ & $0.98( \pm 0.00)$ & $2.19( \pm 0.15)$ \\
SH-Mixed reef & $11.00( \pm 2.00)$ & $24.27( \pm 5.89)$ & $3.14( \pm 0.39)$ & $0.95( \pm 0.02)$ & $2.27( \pm 0.22)$ \\
SH & $10.33( \pm 1.29)$ & $367.67( \pm 97.22)$ & $1.64( \pm 0.21)$ & $0.57( \pm 0.06)$ & $1.34( \pm 0.19)$ \\
Sand & $3.59( \pm 0.36)$ & $5.54( \pm 0.74)$ & $1.52( \pm 0.13)$ & $0.96( \pm 0.01)$ & $1.15( \pm 0.10)$ \\
Mud & $2.73( \pm 0.38)$ & $4.46( \pm 0.62)$ & $1.14( \pm 0.15)$ & $0.94( \pm 0.01)$ & $0.88( \pm 0.11)$ \\
\hline
\end{tabular}

Table 8b: Mean values ( $+\mathrm{SE}$ ) for the infauna community in each habitat sampled by grab of species richness $(S)$, total individual frequency $(N)$, Margalef diversity index ( $d$ '), Pielou's evenness $\left(\mathrm{J}^{\prime}\right)$, and Shannon-Weiner diversity index (H'loge).

\begin{tabular}{lccccc}
\hline Habitat & $\mathbf{S}$ & $\mathbf{N}$ & $\mathbf{d}^{\prime}$ & $\mathbf{J}^{\prime}$ & $\mathbf{H}^{\prime}($ loge $)$ \\
\hline Sand & $107.36( \pm 5.13)$ & $618.79( \pm 60.02)$ & $16.63( \pm 0.60)$ & $0.72( \pm 0.02)$ & $3.34( \pm 0.09)$ \\
Mud & $96.21( \pm 3.17)$ & $309.93( \pm 15.95)$ & $16.62( \pm 0.46)$ & $0.88( \pm 0.01)$ & $4.00( \pm 0.04)$ \\
\hline
\end{tabular}


Video data showed greater fish species richness associated with mud and macro-algal habitats as well as total individual frequency, Margalef diversity index, and S-W diversity. Pielou's evenness values were relatively constant for fish species across all habitats (0.99) with the exception of mixed Reef which was lower (0.95, Table 9). However, DIVERSE analysis of the fish community showed no significant differences in the diversity indices for the sampled habitat categories for fish species richness $\left(X^{2}{ }_{(2)}=1.858, p=0.395\right)$, total individual frequency $\left(X^{2}{ }_{(2)}=1.623, p=0.444\right)$, Pielou's evenness (ANOVA F $\left.(2,19)=0.087, p=0.917\right), \mathrm{S}-\mathrm{W}$ diversity $\left(X^{2}{ }_{(2)}=0.386, p=0.386\right)$, and Margalef diversity index $\left(X^{2}{ }_{(2)}=1.934, p=0.380\right)$.

Table 9: Mean values of species richness (S), total individual frequency (N), Margalef diversity index ( $\left.d^{\prime}\right)$, Pielou's evenness $\left(J^{\prime}\right)$, and Shannon-Weiner diversity index ( $\left.H^{\prime} \log _{e}\right)$ for fish community in each habitat sampled by video surveys ( \pm standard error).

\begin{tabular}{lccccc}
\hline Habitat & $\mathbf{S}$ & $\mathbf{N}$ & $\mathbf{d}^{\prime}$ & $\mathbf{J}^{\prime}$ & $\mathbf{H}^{\prime}($ loge $)$ \\
\hline SH-Macroalgal & $5.00( \pm 0.00)$ & $5.38( \pm 0.00)$ & $2.38( \pm 0.00)$ & $1.00( \pm 0.00)$ & $1.61( \pm 0.00)$ \\
SH-Oyster Bed & $4.00( \pm 0.00)$ & $4.83( \pm 0.00)$ & $1.91( \pm 0.00)$ & $0.99( \pm 0.00)$ & $1.37( \pm 0.00)$ \\
SH-Coral Reef & $3.00( \pm 0.00)$ & $3.00( \pm 0.00)$ & $1.82( \pm 0.00)$ & $1.00( \pm 0.00)$ & $1.10( \pm 0.00)$ \\
SH-Mixed Reef & $2.00( \pm 0.00)$ & $2.68( \pm 0.00)$ & $1.01( \pm 0.00)$ & $0.95( \pm 0.00)$ & $0.66( \pm 0.00)$ \\
SH & $3.50( \pm 0.65)$ & $3.97( \pm 0.67)$ & $1.78( \pm 0.28)$ & $0.98( \pm 0.01)$ & $1.18( \pm 0.20)$ \\
Sand & $3.67( \pm 0.91)$ & $4.49( \pm 1.18)$ & $1.73( \pm 0.27)$ & $0.99( \pm 0.20)$ & $1.10( \pm 0.02)$ \\
Mud & $5.00( \pm 1.13)$ & $6.21( \pm 1.40)$ & $2.14( \pm 0.32)$ & $0.99( \pm 0.19)$ & $1.42( \pm 0.02)$ \\
\hline
\end{tabular}

\section{Habitats with Depth}

The most abundant habitats in the $10-20 \mathrm{~m}$ depth range were the structured habitats (coral/mixed reef, oyster bed, and macroalgae) which represented $53.3 \%$ of the observed habitat types. From 21 to $30 \mathrm{~m}$, only one structured habitat (macroalgae) was present, while the proportion of sand and mud habitats increased. From 31 to $40 \mathrm{~m}$, only mud and sand habitats were found, and below $40 \mathrm{~m}$ mud was the only habitat observed. A chi-square test for association determined that there was a significant relationship between habitats observed and depth $\left(X^{2}(20)=616.156, p=<0.001\right)$. There was a strong association between depth and habitat type (Cramér's V $=0.564, p=<0.001$ ) (Figure 4). 


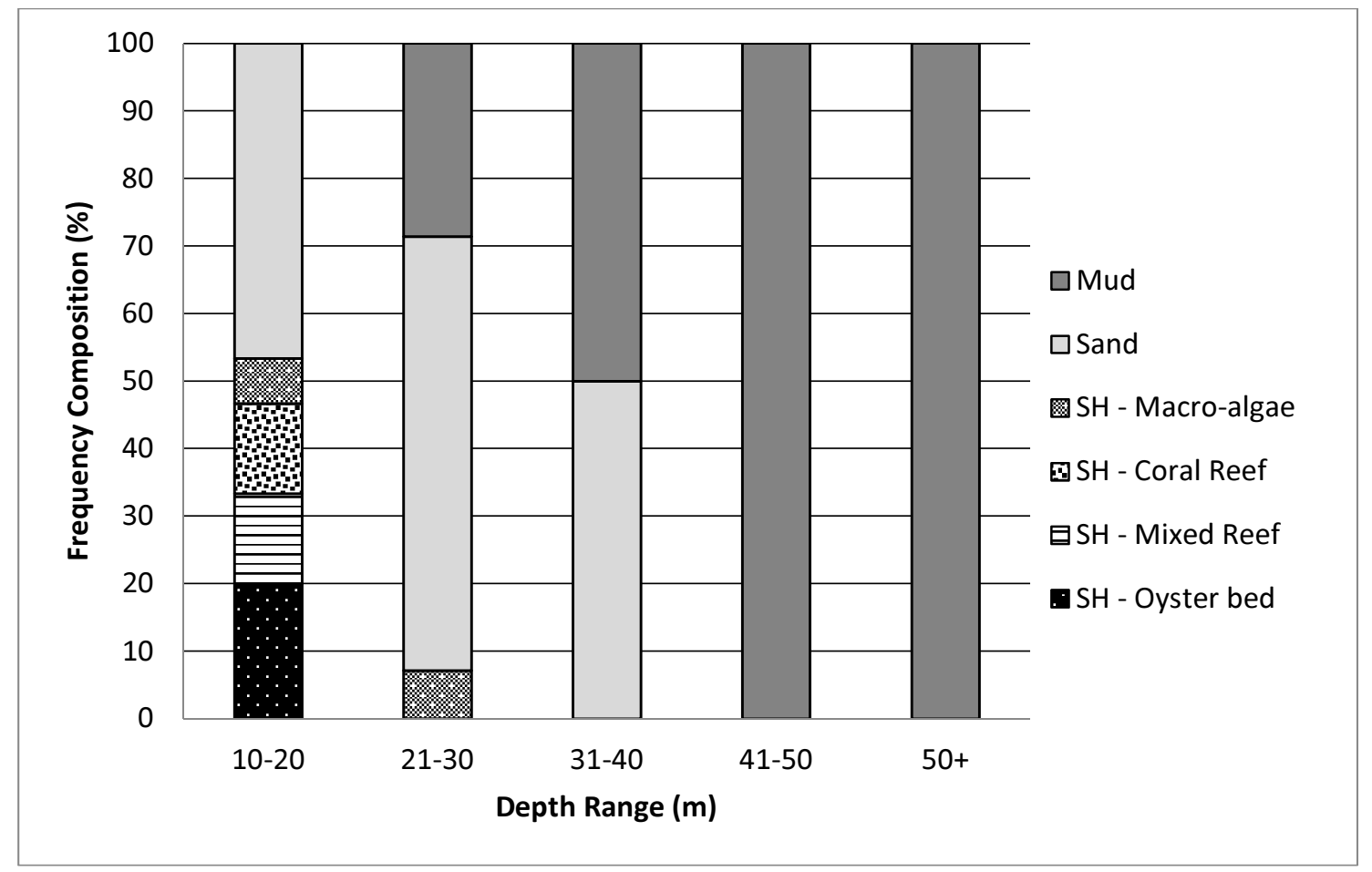

Figure 4: Relationship between depth and percentage frequency of benthic habitat categories in the offshore waters of Qatar. SH = structured habitat

\section{Prediction of Spatial Distribution of Habitats}

Using the close relationship between habitat and depth data, multinominal probit analysis determined the depth range at which each of the habitats were likely to be present as structured $<14 \mathrm{~m}$, structured to sand 14-19 m, sand 20-27 m, sand to mud 26-35 m, and mud $>36 \mathrm{~m}$. Transitional habitats eg. sand to mud were composed of a mosaic of sand and mud areas. These groupings were used to predict spatial distributions for each habitat (Figure 5). A linear regression t-test indicated there was no difference between the observed and predicted habitats at each site ( $\mathrm{t}(88)=1.91, p=0.06$ ), with the habitat prediction map achieving an accuracy of $93.48 \%$. 


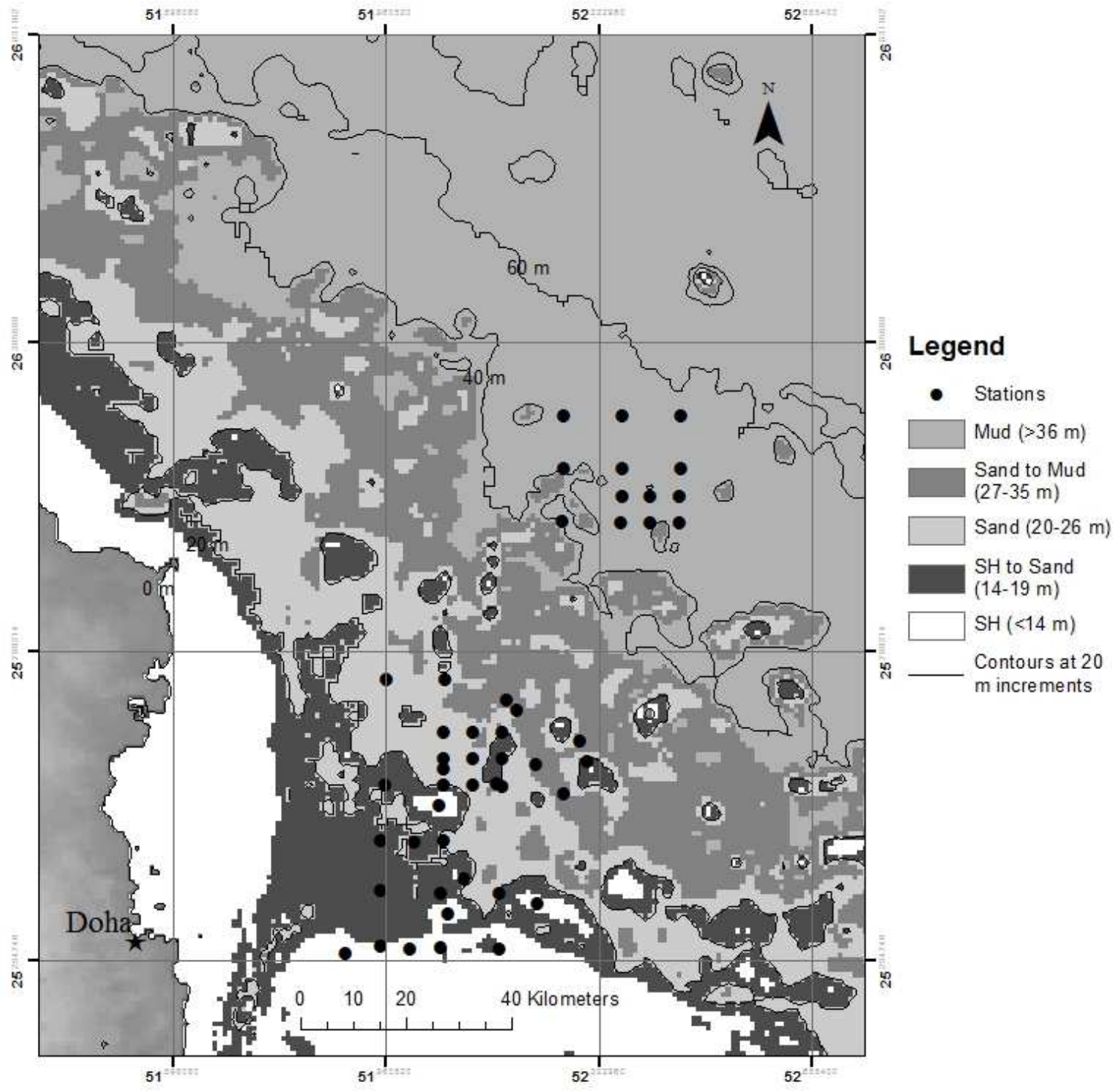

Figure 5: ArcGIS map predicting habitats present in Qatari Waters to the North-East of Doha. Contour lines are depth increments of $20 \mathrm{~m}$.

\section{Commercial Fisheries Trawl Survey}

The survey trawls covered $0.003-0.004 \%$ of the trawlable area within the Qatar EEZ, with individual trawls covering approximately $0.05 \mathrm{~km}^{2}$. Resulting mean catch rates ranged between 547 and $740 \mathrm{~kg} \mathrm{~km}^{-2}$, of which less than half the biomass was due to the 12 most exploited commercial species. Fish catches over the habitat classifications indicates that some species such as the lethrinids and the sparids, with the exception of Agyrops spinifer, were more abundant over the shallow structured habitats, while the groupers and $A$. spinifer were found over the deeper sand to mud habitats (Figure 6). The transitional habitats (structuredsand, sand-mud) had the highest mean ( $\pm \mathrm{SE}$ ) fish biomass and resulted in the highest catches

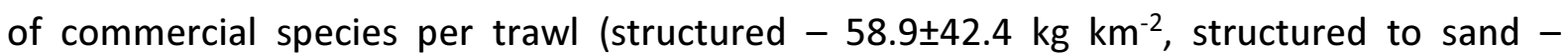
$171.3 \pm 39.0 \mathrm{~kg} \mathrm{~km}^{-2}$, sand $-80.3 \pm 30.5 \mathrm{~kg} \mathrm{~km}^{-2}$, sand to mud $-121.1 \pm 43.6 \mathrm{~kg} \mathrm{~km}^{-2}$, and mud $34.4 \mathrm{~kg} \pm 10.2 \mathrm{~km}^{-2}$ ). However, analysis of variance suggested there was no significant 
difference $(F=2.25, p=0.072)$ between the log transformed catch rates from the different habitats.

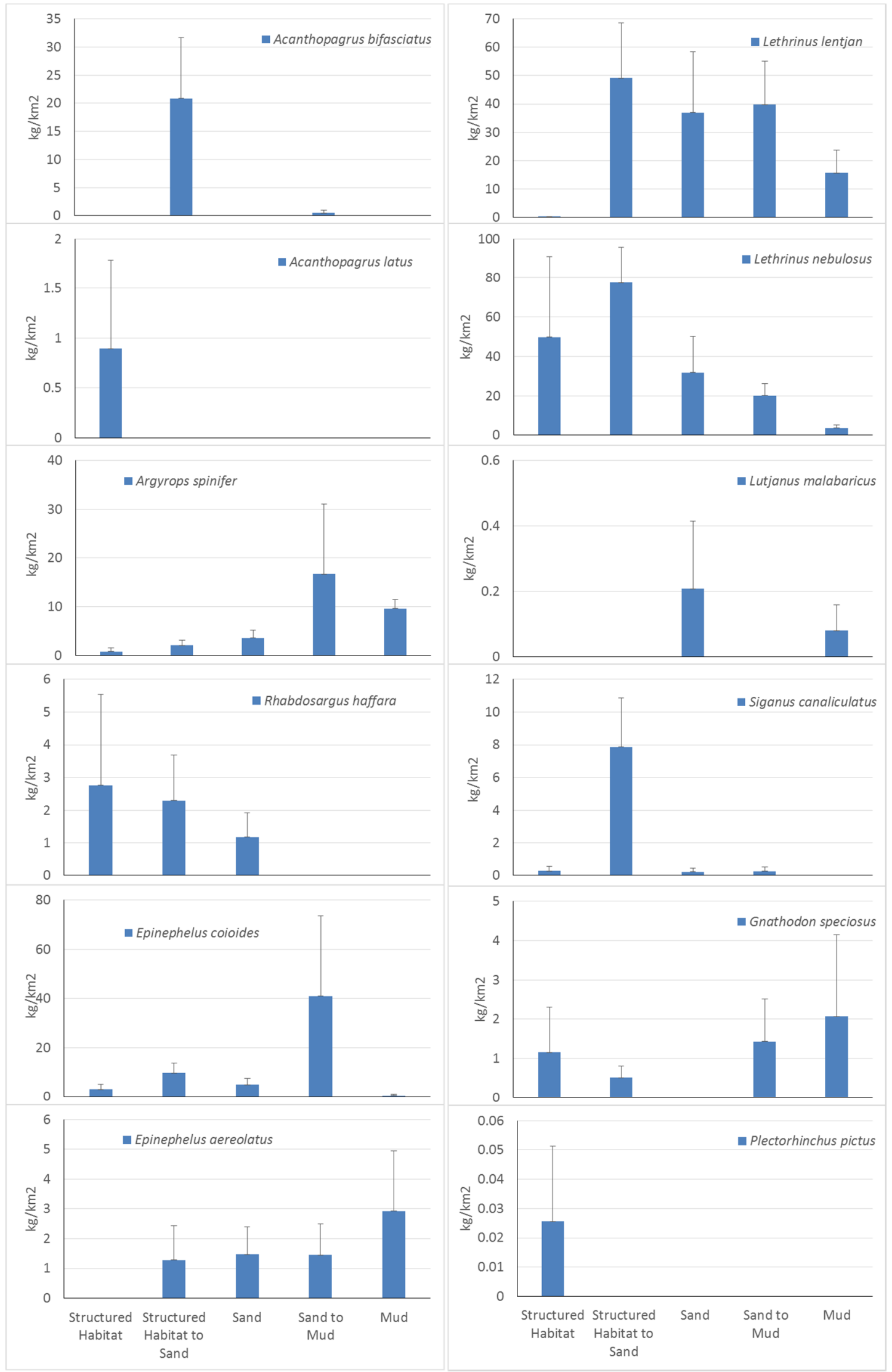


Figure 6: Mean trawl catch rates and standard error $\left(\mathrm{kg} \mathrm{km}^{-2}\right)$ for the 12 most commercially important species.

\section{Discussion}

In the offshore waters west of Qatar (10 to $70 \mathrm{~m}$ ) six habitat types were identified using the guidelines presented in lerodiaconou et al. (2011): two soft sediment habitats of mud and sand and four structured habitats: coral reef, mixed reef, macro-algal and oyster bed. Sea bed video footage was used as a cost-effective method to identify the range of epibenthic species present over each of these habitats. While identification was not always possible to species level this is not problematic as the use of coarser taxonomic classification when combined with morphological differences correlates well with actual species diversity (Bell and Barnes 2001, Althaus et al. 2015, Monk et al. 2016). Epibenthic species assemblages differed between habitats, with certain organisms being characteristic of a habitat such as sea pens in mud habitats. While sand habitats were noticeably impoverished in terms of epibenthos, low densities of all the species recorded in the other surveyed habitats also occurred here. This is in notable contrast to previous work that found higher diversity in sand compared with mud subtidal habitats (Sanders 1968). Although more recently it has been suggested that grain size alone is unlikely to result in the diversity differences reported as many other variables are cocorrelated (Snelgrove and Butman 1995).

The differences in species assemblages found between the complex limestone-outcrop structured habitats of oyster bed, mixed reef and coral reef and the homogeneous softsediment sand and mud habitats were further supported by the diversity indices. These indices also indicated significantly greater eipbenthic diversity over the more complex habitats compared to those more homogeneous sand and mud habitats. Previous studies have reported low diversity in the Gulf (Price 1982, Sheppard et al. 1992) due to the stress caused by the harsh environmental conditions of extreme sea temperatures $\left(10-40^{\circ} \mathrm{C}\right)$ and high salinities (36-60 ppt) (Sheppard et al. 1992, Al-Maslamani et al. 2007), combined with the geographic semi-isolation of the Gulf due to the restricted water exchange through the Strait of Hormuz (Wilson et al. 2002). Comparable epibenthic diversity studies using a towed camera system are rare, but one study in Cardigan Bay Special Area of Conservation (SAC) on the Welsh coast found very similar S-W diversity levels of between 1.2 to 2.6 over sand and gravel at depths of 3-12 m (Sciberras et al. 2013) compared with the current study in Qatar waters where S-W diversity varied between 0.9 to 2.3. Similar levels of S-W diversity was also reported using towed cameras on the Greenland continental shelf on both hard and soft substrates, of 0.1 to 2.5 (Yesson et al. 2015) and using autonomous underwater vehicle reef and soft sediments in Tasmania of 0.13 and 1.98 (Monk et al. 2016). Trawling for benthic epifauna from the organically polluted Hong Kong harbour to the less polluted outside channel, indicated the epifaunal S-W diversity indices increased with distance from the harbour from 0.7 to 2.1 (Wu 1982). Overall, these comparisons suggest that the epibenthic diversity in the central Gulf is not impoverished relative to comparable depths in other 
biogeographic regions. This may well reflect intactness of offshore habitats as a result of the bottom trawling ban implemented by Qatar in 1994 (UN 1997), as especially in the deeper areas, sea pens and sea whips were commonly recorded in almost $60 \%$ of the $4.45 \mathrm{~m}^{2}$ quadrants in mud habitats. However, although some fish species were only found in certain habitats, neither fish diversity nor fish species composition based on camera data differed significantly between habitats. Slightly higher infauna S-W diversity (converted to $\mathrm{H}^{\prime} \log _{\mathrm{e}}$ ) has been reported in similar muddy habitats and depths in the Indian Ocean off Madagascar (4.4), with lower diversity in the Arabian Sea (2.1 off Mumbai and 1.8 off Kerala) although these might be the result of an annual hypoxia event (Sanders 1968). However, the deeper muddy areas sampled in the current Gulf study are also thought to experience a similar hypoxia event during the summer (Al-Ansari et al. 2015). The first quantitative study on trawling impacts, found that increasing bottom trawling activity from 1.3 to 18.2 times a year decreased infauna abundance by $72 \%$, biomass by $77 \%$ and species richness by $40 \%$ (Hinz et al. 2009). Similar inference have been made from a study on Georges Bank with areas disturbed by dredges/trawling having a lower S-W diversity (2.7) than undisturbed areas (3.2) (Collie et al. 1997). The benthic diversity of the soft sediments sampled with grabs in the current study was surprisingly rich, with higher S-W diversity indices in the muddy furthest offshore area of 4 and lower values in the closer sandier habitat of 3.34 where benthic disturbance as a result of trap-based fishing activity is thought to be higher (M. Abdallah, pers. comm.).

Benthic habitat type in the Gulf waters around Qatar were shown to be strongly correlated with depth. In the offshore shallower waters (10-20 m) four structured habitats on limestone outcrops were sampled, coral reef, oyster beds, macroalgae and mixed reef; these transitioned to sand and then to mud habitats with increasing depth. Multinominal probit analysis resolved the depth transitions between habitats and enabled the production of a predictive habitat map. In the Gulf the photic zone only extends down to 6-15 $\mathrm{m}$ (Sheppard et al. 2010), which is approximately the same depth as the structured habitats. The depth of the photic zone is limited by the resuspension and addition of sediment that results from strong winter North-Westerly winds ("shamal") (Alsharhan and Kendall 2003) which increase turbidity in the water column reducing light penetration. The combination of low light levels and high sedimentation would lead to increased stress levels for photic organisms close to their photosynthetic compensation depth. The frequency of sedimentation events combined with fluctuations in temperature and salinity are likely responsible for the reduced number of coral species in the area (Morelock et al. 1979). The lack of hard substrate in deeper waters further restricts the distribution of photic organisms to the shallow waters over the limestone outcrops ("hairat"), which are geological rather than biogenic features. Oysters beds (Pinctada radiata), depend on phytoplankton and the availability of a suitable settlement substrate and thus appear to be restricted to the photic zone. The resuspension of sediment caused by increased water turbulence during storms and shamals facilitates the movement of fine particles from shallower depths to the deeper low energy waters found offshore (Monroe and Wicander 2011). 
Comparing seabed habitats in Qatar, epibenthic species richness was significantly higher in coral reef, mixed reef and oyster beds, compared with sand and mud habitats. However, the compound diversity indices only found oyster and mixed reef to have significantly higher epibenthic diversity, and none of the habitats had significantly different fish diversity. This is consistent with previous wider regional studies of fish assemblages, which report lower coralassociated fish diversity and biomass within the Gulf compared to the neighbouring waters of the Gulf of Oman and Arabian Sea, attributed to the limited extent and impoverished diversity of corals (Burt et al. 2011, Sale et al. 2011). Fish S-W diversity in Qatari waters was found to vary between 0.7 and 1.6. Fish assemblage S-W diversity recorded by divers on coral reefs in Cape Verde varied between means of 1.8 and 2.6 (Santos et al. 2013), and 0.7 to 4.9 over coral reefs in the Yucatan (Arias-González et al. 2012). Lower diversity was observed in the current study in Qatar, but this was achieved using benthic-focused towed cameras where the field of view might not have captured more mobile fish species. However a diver survey carried out in the same area, found similar S-W diversities of 1.35 and 1.89 over sand and coral reef habitats, respectively (Hayes 2015, Egerton et al. In prep). Trawl catches of the commercial species indicate that the structured habitats are important for some species such as the lethrinids and sparids, but these species are also found in significant numbers in deeper habitats. Moreover deeper habitats of $>27 \mathrm{~m}$ that included the sand-mud and mud habitat classifications are significant areas for other important commercial species such as groupers and $A$. spinifer. It is not known whether the pattern of fish catches observed represents actual habitat use as all trawl surveys were performed during daylight, and nocturnal habitat use would not be captured in the current study. The lack of difference in fish catches and fish biodiversity recorded between the structurally complex shallow structured and deeper less complex habitats may also result from the higher fishing pressure that occurs in these shallower areas as these habitats are targeted as traditional fishing grounds. The damage to epifaunal communities in the retrieval of these traps is of concern (Al-Maslamani et al., in prep). Soak times are normally 3-4 days and fishermen do not use marker buoys, only marking the position of their strings of traps with GPS to reduce the risk of theft. The fishermen therefore have to retrieve the traps with a heavy grapple, and this grapple together with the trap recovery causes extensive physical damage to the benthos.

In conclusion, the study demonstrates the strong influence of depth on benthic habitat type, but not fish community composition, so that depth can be used to predict habitat distribution with a high level of accuracy. Although the shallow structured habitats of reef, mixed reef, oyster beds and macroalgae support higher epibenthic diversity than the deeper habitats (sand, mud) there was no difference in diversity between types of structured habitat. Overall, the presence of outcrops of hard substrata creates a mosaic of patchy shallow structured benthic habitat across extensive areas of the offshore seabed. Such heterogeneity, and the association of commercially-exploited fish species with specific habitats, indicates that this region is well suited to a spatial approach to fisheries management of the sort described by Norse (2010). A similar approach has been used in the development of the marine spatial plan 
of Australia, where distribution of demersal fish and habitats are used to determine benthic bioregions (Commonwealth_of_Australia 2006) onto which human use maps are over laid to guide marine spatial zonation (Norse 2010). In the present study, it was notable that high epibenthic diversity did not translate into high fish diversity and this is supported by the trawl data of the commercial catches that showed trawling over the transitional habitats resulted in the highest catches. Hence, some further work on association of exploited fish species and communities with specific habitats and connectivity between habitats is required, including acoustic studies of fish distribution and abundance over shallow structured habitats (Egerton et al, in press), food web linkages between benthic habitats and demersal fish, and development of better understanding of connectivity through investigation of diurnal, seasonal and ontogenetic patterns of fish movement. Together, this information will give support to potential new management measures, including integration of habitat protection and spatial management of fisheries in the Gulf.

\section{Supplementary data}

Supplementary material is available at the ICESJMS online version of the manuscript (and here at the end of the manuscript).

\section{Acknowledgements}

This research was supported by the project "Identification of Essential Fish Habitat to Achieve An Ecosystem-Based approach to Fisheries Management" funded by the Qatar National Research Foundation (QNRF) NPRP 6-1680-4-027. We would particularly like to thank Jodie Haig, Julia Pantin, Harriet Salomonsen, Gwladys Lambert, Caesar Sorino, Abdulrahman Albinali, Yousif Alkahalaf for participation in survey cruises on the RV Janan, and Ms. Aisha AlAshwel, Ms. Najat Al-Omary and Ms. Noora Ali Alfardi for help with benthic infauna species identification and Manal Ibrahim, Noora Alshammari for fish laboratory work. We would also like to thank the reviewers and the editor, Dr Norkko, whose thoughtful comments greatly improved the manuscript.

\section{References}

Al-Ansari, E., G. Rowe, M.A.R. Abdel-Moati, O. Yigiterhan, I. Al-Maslamani, M.A. Al-Yafei, I. Al-Shaikh, and R. Upstill-Goddard. 2015. Hypoxia in the central Arabian Gulf Exclusive Economic Zone (EEZ) of Qatar during summer season. Estuarine Coastal and Shelf Science 159:60-68. DOI: 10.1016/j.ecss.2015.03.022

Al-Khayat, J., and M. Al-Ansi. 2008. Ecological features of oyster beds distribution in Qatari waters, Arabian Gulf. Asian Journal of Scientific Research 1:544-561

Al-Maslamani, I., L. Le Vay, H. Kennedy, and D.A. Jones. 2007. Feeding ecology of the grooved tiger shrimp Penaeus semisulcatus De Haan (Decapoda : Penaeidae) in inshore waters of Qatar, Arabian Gulf. Marine Biology 150:627-637. DOI: 10.1007/s00227-006-0346-9

Al-Maslamani, I., D. Smyth, B. Giraldes, M. Chatting, M. Al-Mohannadi, and L. Le Vay. In Prep. Is excessive fishing intensity with artisanal gear impeding the recruitment of ecosystem providers onto the historic offshore oyster beds of the western Arabian Gulf? 
Al-Zaidan, A.S.Y., H. Kennedy, D.A. Jones, and S.Y. Al-Mohanna. 2006. Role of microbial mats in Sulaibikhat Bay (Kuwait) mudflat food webs: evidence from delta C-13 analysis. Marine Ecology-Progress Series 308:27-36

Al Ansi, M.A., and J.A. Al-Khayat. 1999. Preliminary study on coral reef and its associated biota in Qatari waters, Arabian Gulf. Qatar University Science Journal 19:294-311

Alsharhan, A.S., and C.G.S.C. Kendall. 2003. Holocene coastal carbonates and evaporites of the southern Arabian Gulf and their ancient analogues. Earth-Science Reviews 61:191-243. DOI: http://dx.doi.org/10.1016/S0012-8252(02)00110-1

Althaus, F., N. Hill, R. Ferrari, L. Edwards, R. Przeslawski, C.H.L. Schönberg, R. Stuart-Smith, N. Barrett, G. Edgar, J. Colquhoun, M. Tran, A. Jordan, T. Rees, and K. Gowlett-Holmes. 2015. A Standardised Vocabulary for Identifying Benthic Biota and Substrata from Underwater Imagery: The CATAMI Classification Scheme. Plos One 10:e0141039. DOI: 10.1371/journal.pone.0141039

Arias-González, J.E., G. Acosta-González, N. Membrillo, J.R. Garza-Pérez, and J.M. Castro-Pérez. 2012. Predicting spatially explicit coral reef fish abundance, richness and Shannon-Weaver index from habitat characteristics. Biodiversity and Conservation 21:115-130. DOI: 10.1007/s10531-011-0169-y

Bell, J.J., and D.K.A. Barnes. 2001. Sponge morphological diversity: a qualitative predictor of species diversity? Aquatic Conservation: Marine and Freshwater Ecosystems 11:109-121. DOI: 10.1002/aqc. 436

Burt, J.A., D.A. Feary, A.G. Bauman, P. Usseglio, G.H. Cavalcante, and P.F. Sale. 2011. Biogeographic patterns of reef fish community structure in the northeastern Arabian Peninsula. ICES Journal of Marine Science: Journal du Conseil 68:1875-1883

CBD. 2010. The strategic plan for biodiversity 2011-2020 and the Aichi Biodiversity Targets. Conference of Parties to the Convention on Biological Diversity at its Tenth Meeting, UNEP/CBD/COP/DEC/X/2, Nagoya, Japan.

CBD. 2016. CBD-Country Profile-State of Qatar https://www.cbd.int/countries/profile/?country=qa. Clarke, K.R., and R.N. Gorley. 2006. PRIMER V6: user manual-tutorial. Plymouth Marine Laboratory.

Collie, J.S., G.A. Escanero, and P.C. Valentine. 1997. Effects of bottom fishing on the benthic megafauna of Georges Bank. Marine Ecology Progress Series 155:159-172

Commonwealth_of_Australia. 2006. A guide to the integrated marine and coastal regionalisation of Australia. Version 4.0. 16

Duarte, C.M., and C.L. Chiscano. 1999. Seagrass biomass and production: a reassessment. Aquatic Botany 65:159-174. DOI: http://dx.doi.org/10.1016/S0304-3770(99)00038-8

Egerton, J., M. Al Ansi, M. Abdallah, M.E.M. Walton, J. Hayes, J.R. Turner, I. Al-Maslamani, M. Mohannadi, and L. Le Vay. In prep. Fish association with shallow offshore habitats in the Arabian Gulf.

ESRI. 2011. ArcGIS Desktop Release 10. Redlands, CA: Environmental Systems Research Institute.

FAO. 2003. Fishery Country Profile: Qatar. (ftp://ftp.fao.org/FI/DOCUMENT/fcp/en/FI CP QA.pdf). FAO, Rome.

GEBCO. 2015. GEBCO. [Online] Available at http://gebco.net/. [Accessed 17/09/15]. .

Hayes, J. 2015. Distribution and species diversity of offshore benthic habitats in the exclusive economic zone of Qatar, Arabian Gulf. Ocean sciences, Bangor University. MSc Thesis. pp 76. 
Hinz, H., V. Prieto, and M.J. Kaiser. 2009. Trawl disturbance on benthic communities: chronic effects and experimental predictions. Ecological Applications 19:761-773

Hunter, J. 1983. Aspects of the dynamics of the residual circulation of the Arabian Gulf. Pages 31-42 Coastal oceanography. Springer. ISBN: 1461566509. DOI: 10.1007/978-1-4615-6648-9_3

lerodiaconou, D., L. Laurenson, S. Burq, and M. Reston. 2007. Marine benthic habitat mapping using Multibeam data, georeferencedvideo and image classification techniques in Victoria, Australia. Journal of Spatial Science 52:93-104. DOI: 10.1080/14498596.2007.9635105

lerodiaconou, D., J. Monk, A. Rattray, L. Laurenson, and V. Versace. 2011. Comparison of automated classification techniques for predicting benthic biological communities using hydroacoustics and video observations. Continental Shelf Research 31:S28-S38

Jones, D.A., A.R.G. Price, F. Al-Yamani, and A. Al-Zaidan. 2002. Coastal and marine ecology. Pages 65103 in M. M. Kahn NY, Price ARG., editor. The Gulf Ecosystem; health and sustainability. Ecovision World Monograph Series, Bakhuys, Leiden.

Kaiser, M.J., J.S. Collie, S.J. Hall, S. Jennings, and I.R. Poiner. 2002. Modification of marine habitats by trawling activities: prognosis and solutions. Fish and Fisheries 3:114-136

Monk, J., N.S. Barrett, N.A. Hill, V.L. Lucieer, S.L. Nichol, J.P.W. Siwabessy, and S.B. Williams. 2016. Outcropping reef ledges drive patterns of epibenthic assemblage diversity on cross-shelf habitats. Biodiversity and Conservation 25:485-502. DOI: 10.1007/s10531-016-1058-1

Monroe, J.S., and R. Wicander. 2011. The changing earth: exploring geology and evolution. Cengage Learning.1133715516.

Morelock, J., K. Boulon, and G. Galler. 1979. Sediment Stress Coral Reefs. . Pages 46-58 In: Proceedings, Energy Industry and the Marine Environment in Guayanilla Bay. Centre for Energy and Environmental Research, the University of Puerto Rico

Naser, H.A. 2014. Marine ecosystem diversity in the Arabian Gulf: threats and conservation. Pages 297-328 Biodiversity-The Dynamic Balance of the Planet. INTECH. ISBN: 978-953-51-1315-7. DOI: $10.5772 / 57425$

Norse, E.A. 2010. Ecosystem-based spatial planning and management of marine fisheries: why and how? Bulletin of Marine Science 86:179-195

Price, A. 1982. Comparison between echinoderm faunas of Arabian Gulf, SE Arabia, Red Sea and Gulfs of Aqaba and Suez. Fauna of Saudi Arabia 4:3-21

Price, A.R.G., and C. Izsak. 2005. Is the Arabian Gulf really such a lowspot of biodiversity?: Scaling effects and management implications. Aquatic Ecosystem Health \& Management 8:363-366. DOI: $10.1080 / 14634980500457757$

Quinn, G.P., and M.J. Keough. 2002. Experimental design and data analysis for biologists. Cambridge University Press.0521009766.

Riegl, B. 1999. Corals in a non-reef setting in the southern Arabian Gulf (Dubai, UAE): fauna and community structure in response to recurring mass mortality. Coral Reefs 18:63-73

Riegl, B.M., S.J. Purkis, A.S. Al-Cibahy, M.A. Abdel-Moati, and O. Hoegh-Guldberg. 2011. Present limits to heat-adaptability in corals and population-Level responses to climate extremes. Plos One 6. DOI: 10.1371/journal.pone.0024802

Sale, P.F., D.A. Feary, J.A. Burt, A.G. Bauman, G.H. Cavalcante, K.G. Drouillard, B. Kjerfve, E. Marquis, C.G. Trick, P. Usseglio, and H. Van Lavieren. 2011. The growing need for sustainable ecological management of marine communities of the Persian Gulf. Ambio 40:4-17. DOI: 10.1007/s13280-010-0092-6 
Sanders, H.L. 1968. Marine Benthic Diversity: A Comparative Study. The American Naturalist 102:243-282

Santos, M.N., M.T. Oliveira, and J. Cúrdia. 2013. A comparison of the fish assemblages on natural and artificial reefs off Sal Island (Cape Verde). Journal of the Marine Biological Association of the United Kingdom 93:437-452. DOI: doi:10.1017/S0025315412001051

Sciberras, M., H. Hinz, J.D. Bennell, S.R. Jenkins, S.J. Hawkins, and M.J. Kaiser. 2013. Benthic community response to a scallop dredging closure within a dynamic seabed habitat. Marine Ecology Progress Series 480:83-98

Sheppard, C., M. Al-Husiani, F. Al-Jamali, F. Al-Yamani, R. Baldwin, J. Bishop, F. Benzoni, E. Dutrieux, N.K. Dulvy, S.R.V. Durvasula, D.A. Jones, R. Loughland, D. Medio, M. Nithyanandan, G.M. Pilling, I. Polikarpov, A.R.G. Price, S. Purkis, B. Riegl, M. Saburova, K. Samimi-Namin, O. Taylor, S. Wilson, and K. Zainal. 2010. The Gulf: A young sea in decline. Marine Pollution Bulletin 60:13-38. DOI: 10.1016/j.marpolbul.2009.10.017

Sheppard, C., A. Price, and C. Roberts. 1992. Marine ecology of the Arabian region: Patterns and processes in extreme tropical environments. Academic Press, London.

Smyth, D., I. Al-Maslamani, M. Chatting, and B. Giraldes. 2016. Benthic surveys of the historic pearl oyster beds of Qatar reveal a dramatic ecological change. Marine Pollution Bulletin. DOI: http://dx.doi.org/10.1016/j.marpolbul.2016.08.085

Snelgrove, P., and C. Butman. 1995. Animal-sediment relationships revisited: cause versus effect. Oceanographic Literature Review 8:668

SPSS. 2013. IBM SPSS Statistics for Windows. 20. Armonk, NY: IBM Corp

UN. 1997. Qatar country profile. United Nations Commission on Sustainable Development, New York UNEP. 2009. Second National Human Development Report Qatar: Advancing Sustainable Development. Qatar National Vision 2030. General Secretariat for Development Planning, Doha, Qatar. 1-136

Walton, M.E.M., I. Al-Maslamani, N. Haddaway, H. Kennedy, A. Castillo, E.S. Al-Ansari, I. Al-Shaikh, M. Abdel-Moati, M.A.A. Al-Yafei, and L. Le Vay. 2016. Extreme 15N Depletion in Seagrasses. Estuaries and Coasts:1-15. DOI: 10.1007/s12237-016-0103-3

Walton, M.E.M., I. Al-Maslamani, M.W. Skov, I. Al-Shaikh, I.S. Al-Ansari, H.A. Kennedy, and L. Le Vay. 2014. Outwelling from arid mangrove systems is sustained by inwelling of seagrass productivity. Marine Ecology Progress Series 507:125-137

Wilson, S., S.M.R. Fatemi, M.R. Shokri, and M. Claereboudt. 2002. Status of coral reefs of the Persian/Arabian Gulf and Arabian Sea region. Pages 53-62 in C. Wilkinson, editor. Status of coral reefs of the world.

Wu, R.S.S. 1982. Periodic defaunation and recovery in a subtropical epibenthic community, in relation to organic pollution. Journal of Experimental Marine Biology and Ecology 64:253269. DOI: http://dx.doi.org/10.1016/0022-0981(82)90013-2

Yesson, C., P. Simon, I. Chemshirova, T. Gorham, C.J. Turner, N. Hammeken Arboe, M.E. Blicher, and K.M. Kemp. 2015. Community composition of epibenthic megafauna on the West Greenland Shelf. Polar Biology 38:2085-2096. DOI: 10.1007/s00300-015-1768-y 
Supplement 1: Mean depth of fisheries survey trawl stations.

\begin{tabular}{cccc} 
Station No & No of trawls & Mean Depth $(\mathrm{m})$ & StDev \\
\hline 1 & 5 & 23.9 & 0.92 \\
\hline 2 & 5 & 9.32 & 1.48 \\
\hline 4 & 5 & 16.9 & 1.68 \\
\hline 5 & 5 & 18.7 & 2.59 \\
\hline 6 & 5 & 20.2 & 3.81 \\
\hline 7 & 5 & 28.5 & 1.37 \\
\hline 8 & 5 & 18.3 & 1.21 \\
\hline 9 & 5 & 46.3 & 0.67 \\
\hline 10 & 5 & 40.5 & 1.21 \\
\hline 11 & 5 & 29.1 & 1.04 \\
\hline 12 & 5 & 30.8 & 7.48 \\
\hline 13 & 5 & 46.9 & 0.55 \\
\hline 14 & 5 & 26.1 & 1.62 \\
\hline 15 & 5 & 67.6 & 5.03 \\
\hline 16 & 5 & 23.7 & 1.35 \\
\hline
\end{tabular}

Supplement 2: Phylum, Class, Family, Taxon and Authority of all the marine species observed during the survey performed from the RV Janan between the years 2013 - 2015.

\begin{tabular}{|c|c|c|c|c|}
\hline Phylum & Class & Family & Taxon & Authority \\
\hline Annelida & Polychaeta & Sabellidae & Genus: Sabellastarte & Krøyer, 1856 \\
\hline Arthropoda & Malacostraca & & Sugerfamily: Paguroidea & Latreille, 1802 \\
\hline \multirow{2}{*}{ Chordata } & \multirow{2}{*}{ Actinopterygii } & \multirow{2}{*}{ Apistidae } & \multirow{2}{*}{ Apistus carinatus } & Bloch and \\
\hline & & & & Schneider, 1801 \\
\hline & & \multirow[t]{4}{*}{ Carangidae } & Selaroides leptolepis & G. Cuvier, 1833 \\
\hline & & & Selar crumenophthalmus & Bloch, 1793 \\
\hline & & & Seriolina nigrofasciata & Rüppell, 1829 \\
\hline & & & Carangoides coeruleopinnatus & Rüppell, 1830 \\
\hline & & Clupeidae & Nematalosa nasus & Bloch, 1795 \\
\hline & & Dussumieriidae & Genus: Dussumieria & $\begin{array}{c}\text { Valenciennes, } \\
1847\end{array}$ \\
\hline & & \multirow{2}{*}{ Engraulidae } & \multirow{2}{*}{ Thryssa vitrirostris } & Gilchrist and \\
\hline & & & & Thompson, 1908 \\
\hline & & \multirow{2}{*}{ Gobiidae } & \multirow{2}{*}{ Valenciennea persica } & Hoese and \\
\hline & & & & Larson, 1994 \\
\hline & & \multirow[t]{2}{*}{ Lutjanidae } & Lutjanus lutjanus & Bloch, 1790 \\
\hline & & & Lutjanus fulviflamma & Forsskål, 1775 \\
\hline & & - & Genus: Lutjanus & Bloch, 1790 \\
\hline & & \multirow[t]{3}{*}{ Mullidae } & Upeneus doriae & Günther, 1869 \\
\hline & & & \multirow{2}{*}{ Upeneus torres } & Uiblein and \\
\hline & & & & Gledhill, 2015 \\
\hline
\end{tabular}




\begin{tabular}{|c|c|c|c|c|}
\hline & & & Parpeneus margaritatus & $\begin{array}{l}\text { Randall and } \\
\text { Guézé, } 1984\end{array}$ \\
\hline & & & Parupeneus barberinus & Lacépède, 1801 \\
\hline & & - & Family: Mullidae & Rafinesque, 1810 \\
\hline & & Nemipteridae & Nemipterus peronei & $\begin{array}{c}\text { Valenciennes, } \\
1830\end{array}$ \\
\hline & & & Nemipterus bipunctatus & $\begin{array}{c}\text { Valenciennes, } \\
1830\end{array}$ \\
\hline & & Paralichthyidae & Pseudorhombus elavatus & Ogilby, 1912 \\
\hline & & - & Family: Pomacanthidae & \\
\hline & & Pseudochromidae & Pseudochromis aldabraensis & Boutin, 1958 \\
\hline & & Pomacanthidae & Pomacanthus maculosus & Forsskål, 1775 \\
\hline \multirow[t]{14}{*}{ Phylum } & Class & Family & Taxon & Authority \\
\hline & & - & Family: Scaridae & Rafinesque, 1810 \\
\hline & & Serranidae & Epinephelus coioides & Hamilton, 1822 \\
\hline & & & Aethaloperca roga & Forsskål, 1775 \\
\hline & & - & Family: Epinephelinae & \\
\hline & & Sillago & Sillago sihama & Forsskål, 1775 \\
\hline & & Sphyraenidae & Sphyraena jello & Cuvier, 1829 \\
\hline & & Synodontidae & Synodus indicus & Day, 1873 \\
\hline & & & Synodus dermatogenys & Fowler, 1912 \\
\hline & & Triglidae & Lepidotrigla bispinosa & $\begin{array}{c}\text { Steindachner, } \\
1898\end{array}$ \\
\hline & & & Pterygotrigla arabica & Boulenger, 1888 \\
\hline & Ascidiacea & Ascidiiae & Phallusia nigra & Savigny,1816 \\
\hline & Chondrichthyes & Carcharhinidae & Carcharhinidae limbatus & $\begin{array}{l}\text { J.P. Müller and } \\
\text { Henle, } 1839\end{array}$ \\
\hline & Reptilia & Elapidae & Hydrophis lapemoides & Gray, 1849 \\
\hline \multirow[t]{13}{*}{ Cnidaria } & Anthozoa & - & Family: Mussidae & Ortmann, 1890 \\
\hline & & Dendrophylliidae & Turbinaria peltata & Esper, 1794 \\
\hline & & Siderastreidae & Siderastrea savignyana & $\begin{array}{l}\text { Vaughan and } \\
\text { Wells, } 1943\end{array}$ \\
\hline & & Poritidae & Porites lutea & $\begin{array}{c}\text { Quoy and } \\
\text { Gaimard, } 1833\end{array}$ \\
\hline & & Faviidae & Genus: Favia & Oken, 1815 \\
\hline & & & Favia speciosa & Dana, 1846 \\
\hline & & & Genus: Porites & Link, 1807 \\
\hline & & Acroporidae & Astreopora myriophthalma & Lamarck, 1816 \\
\hline & & Merulinidae & Favites abdita & $\begin{array}{c}\text { Ellis and } \\
\text { Solander, } 1786\end{array}$ \\
\hline & & - & Order: Pennatulacea & Verrill, 1865 \\
\hline & & - & Order: Alcyonacea & Lamouroux, 1812 \\
\hline & & - & Order: Actiniaria & \\
\hline & & - & Subphylum: Medusozoa & Petersen, 1979 \\
\hline \multirow[t]{3}{*}{ Echinodermata } & Asteroidea & & Family: Ophidiasteridae & \\
\hline & & Ophidiasteridae & Linckia multifora & Lamarck, 1816 \\
\hline & & & Linckia guildingii & Gray, 1840 \\
\hline
\end{tabular}




\begin{tabular}{|c|c|c|c|c|}
\hline & Echinoidea & - & Order: Clypeasteroida & \\
\hline \multirow[t]{4}{*}{ Phylum } & Class & Family & Taxon & Authority \\
\hline & & Diadematidae & Diadema setosum & Leske, 1778 \\
\hline & & Echinometridae & Echinometra mathaei & Blainville, 1825 \\
\hline & Holothuroidea & Holothuriidae & Holothuria atra & Jaeger, 1833 \\
\hline \multirow[t]{2}{*}{ Mollusca } & Bivalvia & Pteriidae & Genus: Pinctada & Röding, 1798 \\
\hline & Cephalopoda & Sepiidae & Sepia arabica & Massy, 1916 \\
\hline \multirow[t]{2}{*}{ Porifera } & & & Class: Demospongiae & Sollas, 1885 \\
\hline & Demospongiae & Chalinidae & Genus: Haliclona & Grant, 1863 \\
\hline
\end{tabular}

